\title{
Uniwersytety ludowe - pomiędzy starymi a nowymi wyzwaniami, edited by Tomasz Maliszewski and Małgorzata Rosalska, Toruń 2016, Adam Marszałek Publishing House, 408 pages
}

DOI: $10.14746 /$ bhw.2018.38.14

The editors/authors of the reviewed work have made the subject of their deliberations a unique and specific institution of adult education - the folk university. I consider it important and commendable that this issue be tackled in itself. In the mainstream andragogic discourse, there is no reference to the tradition of adult education, especially those of our country. Texts reflecting the past achievements, which sometimes appear on the periphery of the mainstream, are generally unnoticed and do not contribute to the contemporary approach to adult education. Without discussing the reasons for this, I am very positive about the work being reviewed in this context. It is not only a work that brings forward out a forgotten institution from the past, but above all, a work in which there is a visible attempt in all the texts to point to the values of open universities which determined their popularity and high evaluation by andragogists, as well as their participants, and which have been neglected in today's education of adults. The phenomenon of the folk university, which has various cultural, social and, above all, historical sources and in which it has become visible, can now be an archive for us to reflect on the humanist/hermeneutical education of adults. I consider this aspect to be particularly important. Adult education in contemporary Poland, as well as abroad, is understood in a one-dimensional way. It was dominated by instrumental rationality, which appropriated the space of education to experience the order of action and action, and left aside the experience of the order of understanding, which, as Robert Kwaśnica writes, "is created in conversation or, more broadly, in discursive experience"7. The folk university was a space where it was possible to talk, dialogue, search for common meanings, and not only to acquire competences to act in various areas, although these are also important ${ }^{8}$. These are models that provide us with inspiration in thinking about adult education, the language we describe it in, and above all - education that builds discursive sensitivity, serves to search for the sense of human existence, and gives us a chance to speak in public freely ${ }^{9}$. The reviewed publication, while undertaking the consideration of folk universities, recalls, disseminates and reintroduces these forgotten values into the andragogic discourse. They are extremely important for today's adults - lost, uncertain, looking for a definition of their adulthood and searching for their own biographical path, creating identity.

7 R. KWAŚNICA, Dyskurs edukacyjny po inwazji rozumu instrumentalnego. O potrzebie refleksyjności, Wrocław 2014, p. 61.

${ }^{8}$ A. STOPIŃSKA-PAJĄK, Uniwersytet ludowy w II Rzeczypospolitej. Spoleczno-kulturowa przestrzeń spotkania i dialogu ludzi dorostych, [in:] E. SAPIA-DREWNIAK, J. JANIK-KOMAR (Eds.): Uniwersytety ludowe i inne formy oświaty dorostych, Opole 2010.

9 M.P. MARKOWSKI, Polityka wrażliwości. Wprowadzenie do humanistyki, Kraków 2014, p. 83. 
The second aspect which, in my opinion, should be particularly appreciated, is the fact that the book is the shared work of many scientific communities. This is a very important value today. This collaboration is visible in all areas, both publishing as well as editorial and substantive. First of all, the peer-reviewed collective monograph was published as part of the Szkoła-Państwo-Spoleczeństwo series, whose scientific editor is Prof. Romuald Grzybowski, PhD (University of Gdańsk), as its fifth volume. Therefore, placing the issue of the folk universities among the other issues of the aforementioned triad is, in my opinion, a recognition of the achievements and contribution of the folk universities to shaping the social awareness of Poles. It is also to be hoped that it will contribute to the dissemination of this body of work in a wider, not only andragogic, environment. In addition, the work was published in cooperation with the three institutions: The Kashubian Folk University in Wieżyca, the University of Gdańsk and the Adam Mickiewicz University in Poznań, which is an example to follow and are worthy of recognition. This is not a frequent phenomenon, especially the inclusion of social and educational institutions into scientific cooperation, functioning outside the scientific environment.

A particular dimension that shows the scope of cooperation and cooperation in order to disseminate knowledge about folk universities in Poland, is the list of people involved in the publication, starting with the Editors of the work and ending with the Authors. The scientific editorial work on the reviewed title was carried out by people from two scientific circles - Dr Tomasz Maliszewski is an employee of the Pomeranian Academy in Słupsk, while Dr Małgorzata Rosalska works at the Adam Mickiewicz University in Poznań. The editors of the monograph invited the cooperation of representatives of various academic circles and universities, public and non-public, representatives of various scientific disciplines - history, history of pedagogical thought, andragogists, pedagogues and teachers/ educators and employees of educational institutions. These twenty people - authors of the monographs - covered various aspects and contexts of functioning of folk universities in their texts. The presented texts are grouped in five parts: I - Introduction, II - In the circle of Catholic folk universities, III - The folk university - ideas, concepts and practical solutions, IV - The folk university in Polish pedagogical journals, V - From the Pomeranian region. It is thanks to the scientific editors that they have been developed and arranged in such a way that they have produced a monograph in which the reflections show the folk university as an institution of adult education, which not only helped adults to develop themselves in the past, but can continue to do so today.

The publication Uniwersytety ludowe - pomiędzy starymi a nowymi wyzwaniami is a good example of combining tradition with the present, which gains additional value in the context of the approaching 100th anniversary of Poland's regaining independence. 